\title{
Problematika pada Pelaksanaan Penilaian Pembelajaran Kurikulum 2013
}

\author{
K. Kamiludin ${ }^{1} *$, Maman Suryaman ${ }^{2}$ \\ ${ }^{1}$ Program Studi Pendidikan Dasar, Program Pascasarjana, Universitas Negeri Yogyakarta. Jalan \\ Colombo No.1 Yogyakarta 55281, Indonesia \\ ${ }^{2}$ Jurusan Pendidikan Bahasa dan Sastra Indonesia, Universitas Negeri Yogyakarta. Jalan Colombo \\ No.1 Yogyakarta 55281, Indonesia \\ * Korespondensi Penulis. Email: kamiludin_a@yahoo.com \\ Received: 6 April 2016; Revised:29 June 2016; Accepted: 8 August 2016
}

\begin{abstract}
Abstrak
Penelitian ini dimaksudkan untuk mengetahui pelaksanaan penilaian pembelajaran, problema guru dalam melaksanakan penilaian pembelajaran, dan langkah guru dalam menyiasati problema pelaksanaan penilaian pembelajaran Kurikulum 2013 di SD Negeri Ungaran dan SD Negeri Serayu.Penelitian ini merupakan penelitian kualitatif dengan jenis studi kasus.Subjek penelitian enam guru kelas IV yaitu tiga guru SD Negeri Ungaran dan tiga guru SD Negeri Serayu. Instrumen utama penelitian ini adalah human instrument. Instrumen pendukung menggunakan, pedoman wawancara, alat rekam, dan pedoman observasi. Teknik analsis data yang digunakan adalah analisis interaktif Miles Huberman (pengumpulan data, reduksi, display, dan verifikasi/membuat kesimpulan).Hasil penelitian ini menunjukkan bahwa (1) pelaksanaan penilaian pembelajaran Kurikulum 2013 belum sesuai standar. Enam guru yang menjadi informan, hanya satu guru yang berhasil melaksanakan sesuai standar yakni GS3, (2) problematika pelaksanaan penilaian pembelajaran Kurikulum 2013 meliputi; waktu, pemahaman guru, produktivitas guru, kepedulian guru dan mindset guru, (3) bentuk siasat guru dalam mengatasi problematika yaitu siasat kolektif dan individual.
\end{abstract}

Kata Kunci: pelaksanaan penilaian pembelajaran, dan Kurikulum 2013

\section{Problems of Implementing Learning Assessment of Curriculum 2013}

\begin{abstract}
This study aimed to investigate the implementation of learning assessment of Curriculum 2013, the teachers' problems in conducting learning assessments of Curriculum 2013, and teachers steps in negotiating the problems encountered in the implementation of Curriculum 2013 learning assessment in primary schools Serayu and Ungaran.This was a qualitative research with a case study. The subjects of the research were six teachers of grade IV, three of Ungaran and three of Serayu Elementary Schools. The main instrument was the human instrument. While supporting instruments used interview guid, tape recorder, and observation sheet. The data were analysed using interactive analysis Miles \& Huberman (data collection, reduction, display, and verification/conclude).The results indicate that (1) the implementation of learning assessment of Curriculum 2013 has not met standards. However, of the six teachers who became the subject of study, only one teacher managed to carry outmet standards that was GS3, (2) the problems of learning assessment of Curriculum 2013include; time, teachers 'understanding, teachers' productivity, teachers' awareness and teachers' mindset, (3) the teachers strategy in addressing the problem is the teacher collective and individual strategy.
\end{abstract}

Keywords: assessment of learning and Curriculum 2013

How to Cite: Kamiludin, K., \& Suryaman, M. (2017). Problematika pada pelaksanaan penilaian pembelajaran Kurikulum 2013. Jurnal Prima Edukasia, 5(1), 58-67. doi:http://dx.doi.org/10.21831/jpe.v5i1.8391

Permalink/DOI: http://dx.doi.org/10.21831/jpe.v5i1.8391 


\section{Jurnal Prima Edukasia, 5 (1), January 2017 - 59}

Kamiludin, Maman Suryaman

\section{Pendahuluan}

Perubahan kurikulum dilakukan untuk menjawab tantangan zaman yang terus berubah agar peserta didik mampu bersaing di masa depan. Guru merupakan penentu dalam keberhasilan impelementasi kurikulum. Namun, perubahan kurikulum tidak selalu berakibat baik, apabila tidak sejalan dengan SDM yang memadai dari pelaksana kurikulum. Secanggih apapun kurikulum, tetapi apabila guru sebagai pelaksana tidak bisa menerapkannya maka kurikulum tersebut akan gagal. Dengan demikian, guru haruslah memahami konsep setiap kurikulum yang sedang diberlakukan, baik secara teoritis maupun praktis.

Kurikulum 2013 merupakan peralihan dari KTSP.Ciri khas Kurikulum 2013 yaitu pembelajarannya yang tematik integratif, menggunakan pendekatan saintifik, dan pendekatan penilaian menggunakan pendekatan otentik. Bentuk penilaian dalam kurikulum 2013 terlihat memiliki perbedaan yang cukup mendasar dengan kurikulum sebelumnya. Dengandemikian tidak semua guru memahami secara komperehensif pelaksanaan daripenilaian ontentik dalam kurikulum barutersebut. Hal itulah, salah satu yang alasan menteri pendidikan Anis Baswedan untuk menarik Kurikulum 2013 yang semula diterapkan secara keseluruhan di setiap sekolah, akhirnya ditetapkan hanya pada sekolah yang menjadi piloting projek dan sekolah yang merasa siap dari segi SDM dan sarana/prasarana.

SD Negeri Ungaran dan SD Negeri Serayu merupakan sekolah unggulan di kota Yogyakarta. Sekolah tersebut merupakan sekolah yang dijadikan piloting projek dalam pelaksanaan Kurikulum 2013, sehingga sampai saat ini penerapan Kurikulum 2013 sudah berjalan empat semester. Dari hasil survey awal penelitian di sekolah tersebut terkait implementasi Kurikulum 2013, guru mengaku masih merasa memiliki kendala dalam pelaksanaan penilaian. Kendala yang diungkapkan guru yaitu terkait banyaknya bentuk-bentuk penilian yang membuthkan waktu dan tenaga yang banyak pula untuk melaksanakan penilaian. Hal tersebut yang mendasari penelitian ini dilakukan dengan fokus untuk mengetahui keadaan sesungguhnya tentang masalah-masalah (problematika) yang dihadapai guru dalam melaksanakan penilaian Kurikulum 2013.

\section{Kurikulum 2013}

Print (1993, p.9) "curriculum is defined as all the planned learning opportunities offered to learners by the educational institution and the experiences learners encounther when that curriculum is implemented". Artinya bahwa kurikulum adalah semua rencana pembelajaran yang ditawarkan kepada peserta didik oleh lembaga pendidikan dan pengalaman yang peserta didik temukan pada saat kurikulum diterapkan. Ragan (1966, dalam Nasution, 2011, p.5) mendifinisikan kurikulum "The tendency in recent decades has ben to use the term in a broader sense to refer to the whole life and program of the school". Pokok dari definisi menurut Ragan yakni bahwa kurikulum meliputi seluruh kegiatan, program maupun kehidupan dalam sekolah. Sekolah lah yang bertanggungjawab mengayomi dan mengurusi pengalaman anak/peserta didik. Sekolah yang dimaksud di sini ialah kepala sekolah, guruguru dan penyelenggara pendidikan lainnya. Hal tersebut sejalan dengan pendapat Oliva (1992, p.9) mengatakan bahwa "curriculum is perceived as a plan or program for all the experiences which the learner encounters under the direction of the school".

Jadi dapat disimpulkan bahwa kurikulum adalah seperangkat rencana atau program yang memuat mata pelajaran dan hal-hal yang terkait dalam pendidikan yang digunakan sebagai pedoman penyelenggaraan untuk mencapai tujuan dalam membelajarkan peserta didik dalam suatu pendidikan.

Dalam praktiknya kurikulum pendidikan akan terus berkembang atau berubah. Hal tersebut disebabkan karena perubahan zaman yang terus berkembang dan tantangan-tangan yang dihadapi dalam dunia global. Itulah yang dilakukan pemerintah Indonesia yaitu mengubah KTSP beralih ke Kurikulum 2013.Kurikulum 2013 dikembangkan dengan berbasis kompetensi dan berbasis karakter, sehingga diyakini dapat membekali peserta didik dengan berbagai sifat dan kemampuan yang sesuai dengan tuntunan perkembangan zaman dan teknologi.

Adapun, karakteristik Kurikulum 2013 dirancang menurut Kemendikbud, (2013, p.4) sebagai berikut: (1) mengembangkan keseimbangan antara pengembangan sikap spiritual dan sosial, rasa ingin tahu, kreativitas, kerja sama dengan kemampuan intelektual dan psikomotorik; (2) sekolah merupakan bagian dari masyarakat yang memberikan pengalaman 


\section{Jurnal Prima Edukasia, 5 (1), January 2017 - 60}

Kamiludin, Maman Suryaman

belajar terencana dimana peserta didik menerapkan apa yang dipelajari di sekolah ke masyarakat dan memanfaatkan masyarakat sebagai sumber belajar; (3) mengembangkan sikap, pengetahuan, dan keterampilan serta menerapkannya dalam berbagai situasi di sekolah dan masyarakat; (4) memberi waktu yang cukup leluasa untuk mengembangkan berbagai sikap, pengetahuan, dan keterampilan; (5) kompetensi dinyatakan dalam bentuk kompetensi inti kelas yang dirinci lebih lanjut dalam kompetensi dasar mata pelajaran; (6) kompetensi inti kelas menjadi unsur pengorganisasi (organizing elements) kompetensi dasar, dimana semua kompetensi dasar dan proses pembelajaran dikembangkan untuk mencapai kompetensi yang dinyatakan dalam kompetensi inti; (7) kompetensi dasar dikembangkan didasarkan pada prinsip akumulatif, saling memperkuat (reinforced) dan memperkaya (enriched) antarmatapelajaran dan jenjang pendidikan (organisasi horizontal dan vertikal).

Tujuan Kurikulum 2013 adalah "untuk mempersiapkan manusia Indonesia agar memiliki kemampuan hidup sebagai pribadi dan warga negara yang beriman, produktif, kreatif, inovatif, dan afektif serta mampu berkontribusi pada kehidupan bermasyarakat, berbangsa, bernegara, dan peradaban dunia" (Kemendikbud, 2013, p.4). Oleh karena itu, berpijak dari pernyataan tersebut maka pengembangan kurikulum diharapkan mampu mencapai tujuan pendidikan nasional dalam arti yang sesungguhnya.

\section{Penilaian Otentik Kurikulum 2013}

Penilaian otentik yaitu pengukuran yang bermakna secara signifikan atas hasil belajar peserta didik untuk ranah sikap, keterampilan, dan pengetahuan (Kemendikbud, 2013, p.2). Signifikan yang dimaksud ialah bahwa penilaian dilakukan secara komprehensif, sehingga diperoleh informasi yang lengkap mengenai kemajuan belajar peserta didik. Penilaian dilakukan tidak hanya pada ranah pengetahuan peserta didik pada materi pelajaran, tetapi juga sikap/ahlak dan kinerjanya penting untuk diperhatikan. Karena pada kenyataannya, banyak individu yang memiliki kecerdasan tinggi, tetapi tidak sejalan dengan sikap baik yang dimiliki.

Mardapi (2012, p.166), penilaian otentik merupakan salah satu bentuk penilaian yang menuntut peserta didik menerapkan teori di dunia nyata. Artinya bahwa pembelajaran yang dilaksanakan bukan hanya bersifat teoritis, tetapi juga mementingkan praktisnya. Sehingga, untuk mengakomodir hal itu peserta didik diberikan tugas projek dari teori-teori yang telah dipelajari. Dalam penilaian otentik guru melakukan proses pengumpulan informasi terkait dengan perkembangan belajar yang dilakukan peserta didik dan melibatkannya dalam tugastugas otentik yang bermanfaat, penting dan bermakna (Hosnan, 2014, pp.387-388). Penilaian mementingkan pada proses dan hasil secara bersamaan. Dengan demikian penilaian otentik dimaksudkan untuk memantau setiap perkembangan peserta didik melalui tahapan-tahapan yang dilakukan secara continu. Selain itu juga, penilaian dilakukan tidak hanya dari pihak guru saja, akan tetapi bisa dilakukan oleh teman ataupun dan diri sendiri.

Ciri-ciri penilaian otentik menurut Kunandar (2013, p.38), yaiu: (a) mengukur semua aspek pembelajaran, (b) dilaksanakan ketika dan setelah proses proses pembelajaran berlangsung, (c) menggunakan berbagaimacam teknik dan sumber, (d) dalam mengumpulkan data penilaian tidak hanya mengandalkan tes, (e) tugas yang diberikan kepada peserta didik realita dalam kehidupan sehari-hari, dan (f) penilaian bukan kuantitas, tetapi penekanannya lebih pada kualitas pengetahuan ataupun keahlian peserta didik.

Penilaian yang dilakukan dalam Kurikulum 2013 diarahkan pada aspek sikap, pengetahuan dan keterampilan.(1) Penilaian Aspek Sikap. Penilaian sikap yaitu penilaian yang dilakukan guru untuk mengukur tingkat pencapaian kompetensi sikap peserta didik, dengan aspek yang meliputi menerima, merespon, mengorganisasi, menilai/menghargai dan sikap yang berkarakter (Kunandar, 2013, p.100). Aspek sikap terdiri atas spiritual dan sosial dalam kurikulum 2013. Pada kompetensi sikap penilaian dilaksanakan melalui observasi, penilaian diri, penilaian antarteman, dan jurnal.(2) Penilaian Aspek Pengetahuan. Penilaian pengetahuan yaitu penilaian yang dimaksudkan untuk mengukur tingkat kompetensi kognitif peserta didik. Seberapa jauh pencapaian peserta didik pada suatu kompetensi yang berupa ingatan/ hafalan, pemahaman, penerapan, analisis, sintesis dan evaluasi (C1-C6), merupakan tujuan utama pengukuran dalam penilaian pengetahuan. Dalam kurikulum 2013 aspek pengetahuan yang diukur yaitu pengetahuan faktual, prosedural dan konseptual.Jenis penilaian pada aspek pengetahuan meliputi: tes tulis, tes lisan, dan penugasan. (3) Penilaian Aspek Keteram- 


\section{Jurnal Prima Edukasia, 5 (1), January 2017 - 61}

Kamiludin, Maman Suryaman

pilan. Keterampilan atau dapat disebut psikomotor merupakan kecakapan individu dalam mengerjakan suatu hal. Keterampiran sering dikaitkan dengan gerak fisik atau penggunaan anggota tubuh dalam melakukan kegiatan tertentu yang menghasilkan karya/prestasi. Oleh karena itu, dalam pembelajaran di sekolah penilaian keterampilan penting untuk dilaksanakan. Penilaian keterampilan adalah penilaian yang dilakukan untuk mengukur tingkat pencapaian imitasi, kompetensi keterampilan peserta didik, seperti kemampuan manipulasi, artikulasi, presisi dan naturalisasi (Kunandar, 2013, p.251). Lebih lanjut, Kunandar (2013, p.256), kelebihan penilaian keterampilan yaitu memotivasi peserta didik menunjukkan kemampuannya secara maksimal, secara langsung dapat mengamati keterampilan peserta didik dan pembuktian apa yang telah dipelajari peserta didik secara aplikasi. Sedangkan kekurangannya sulit dilakukan pada jumlah peserta didik yang banyak, membutuhkan kecermatan pada penilaian unjuk kerja dan profesionalisme guru sangat ditekankan karena mengamati/menilai keterampilan yang bervariasi. Adapun jenis penilaian keterampilan dalam kurikulum 2013 meliputi peneilaian projek, kinerja, dan portopolio.

\section{Pembelajaran Tematik-Integratif SD}

Menurut Haylock \& Thangata (2007, p.27) "concept learning is a process by which a learner organizes their experiences, abstracting from a number of exemplars what it is that they have in common and using one concept name to embrace them all'. Di sisi lain, Schunk (2008. p.2) mengungkapkan "learning is an enduring change in behavior, or in the capacity to behave in a given fashion, which results from practice or other forms of experience". Sementara, Kidd \& Czerniawski (2010, p.196) menjelaskan bahwa "learning processes are seen to involve the manipulation of bits and pieces of greater whole using puzzles and problem-solving and applying previous knowledge". Artinya bahwa Pemanfaatan kebingungan dalam belajar dilakukan untuk menyelesaikan permasalahan dengan melibatkan antara ide baru dan konsep pengetahuan yang telah diketahui.

Pembelajaran mempunyai beberapa bentuk/model, salah satunya model pembelajaran tematik yang ditinjau dari pengorganisasian kelompok mata pelajaran yang diajarkan. Menurut Trianto (2010, p.154), Pembelajaran tematik ialah model pembelajaran yang memadukan beberapa materi pembelajaran dari berbagai standar kompetensi dan kompetensi dasar dari satu atau beberapa pelajaran. Pembelajaran tematik integratif diterapkan dengan tujuan agar peserta didik memperoleh pemahaman yang utuh terkait hubungan kebermaknaan antar mata pelajaran secara terintegrasi dan tidak terpisah antar mata pelajaran satu dengan lainnya. Model pembelajaran tematik menurut Majid (2014, p.80) adalah model dalam pembelajaran terpadu yang merupakan suatu sistem pembelajaran yang memungkinkan peserta didik secara individu ataupun kelompok aktif menggali dan menemukan konsep serta prinsip-prinsip keilmuan secara holistik, bermakna, dan otentik.

Pembelajaran tematik integratif merupakan model pembelajaran yang diterapkan pada kurikulum 2013. Pembelajaran ini terintegrasi dari berbagai mata pelajaran (interdisciplinary), yang dihubungkan oleh satu oleh tema sebagai pengikatnya. Guru dapat memilih/menyusun tema-tema tersebut sesuai dengan upgrade peristiwa yang terjadi dan kesusuaiannya di kalangan peserta didik. Dalam model pembelajaran Tematik Integratif, peserta didik tidak lagi belajar IPA, Bahasa Indonesia, Matematika, PPKn, SBDP, dan PJOK. Akan tetapi, peserta didik belajar tema yang didalamnya sudah mencakup semua mata pelajaran dan kompetensinya. Dengan pola Tematik Integratif ini, buku-buku siswa SD tidak lagi dibuat berdasarkan mata pelajaran. Namun, berdasarkan tema yang terdiri atas beberapa mata pelajaran berdasarkan pemilihan Kompetensi Dasar yang relavan.

Penilaian yang digunakan dalam pembelajaran tematik integratif adalah penilaian otentik yang meliputi lima domain yaitu: konsep, proses, aplikasi, kreativitas, dan sikap. Penilaian dalam pembelajaran tematik integratif adalah suatu usaha untuk mendapatkan berbagai informasi secara berkala, berkesinambungan, menyeluruh tentang proses dan hasil dari pertumbuhan dan perkembangan yang telah dicapai oleh anak didik melalui program kegiatan belajar (Depdiknas, 2006, p.14).Penilaian pembelajaran tematik dilakukan pada dua hal, yaitu: pertama, penilaian terhadap proses kegiatan dan kedua, penilaian hasil kegiatan (Prastowo, 2014, p.117).

Penilaian dapat dilakukan secara terencana sesuai dengan aspek kompetensi yang dinilai. Aspek kompetensi yang dinilai dalam pembelajaran tematik integratif adalah kom- 


\section{Jurnal Prima Edukasia, 5 (1), January 2017 - 62}

Kamiludin, Maman Suryaman

petensi sikap, pengetahuan dan keterampilan. Aspek-aspek kompetensi yang disesuaikan dengan penilaian menurut Ahmadi dan Amri (2014, pp.241-242) dilakukan dengan sistematis, menyeluruh, berkesinambungan, objektif, mendidik, dan bermakna.

\section{Metode}

Penelitian ini menggunakan pendekatan kualitatif, dengan jenis penelitian studi kasus. Yin (2012, p.18), ), studi kasus yaitu penelitian yang memanfaatkan multisumber bukti, dilakukan untuk menyelidiki fenomena di dalam konteks kehidupan nyata, jika batas-batas antara fenomena dan konteks penelitian tidak tampak dengan jelas. Studi kasus bertujuan untuk memahami suatu proses, aktifitas, program, individu/kelompok, dan lain-lain, yang terbatas oleh waktu dan aktifitas tertentu.

Penelitian ini dilakukan di SD Negeri Ungaran dan SD Negeri Serayu Yogyakarta pada kelas IV. Adapun, waktu penelitian dilaksanakan selama 4 bulan yaitu dari bulan Februari sampai bulan Mei tahun 2015. Subjek penelitian dalam penelitian ini yakni kepala sekolah, Guru dan siswa. Sedangkan objek penelitian yaitu (1) pelaksanaan penilaian pembelajaran Kurikulum 2013, (2) masalahmasalah yang dihadapi guru pada penilaian pembelajaran tematik integratif; dan (3) upaya yang dilakukan dalam mengatasi masalah tersebut.

Teknik yang digunakan dalam mengumpulkan data yaitu wawancara, observasi dan dokumentasi. instrumen utama merupakan peneliti sendiri dengan bantuan instrument pendukung meliputi pedoman wawancara, pedoman observasi, dan alat rekam.

Untuk meningkatkan derajat kepercayaan data, maka dalam penelitian ini dilakukan/ digunakan kriteria sebagai berikut:(1) Peneliti langsung terjun ke lokasi/menyatu dengan konteks penelitian; (2) Peneliti melakukan triangulasi teori, sumber, dan metode; (3) Mengkonfirmasi data-data yang diperoleh dengan informanuntuk mendapatkan objektivitas, kebenaran emik dan interpretif; dan (4) Mengaudit seluruh proses penelitian.

Teknik yang digunakan menganalisis data dalam penelitian ini yaitu model interaktif dari (Miles, Huberman, \& Saldaña, 2014). Analisis data dilakukan secara interaktif dan berlangsung secara berkesinambungan, baik di saat sedang di lapangan maupun setelahnya sampai tuntas, sehingga data yang dihasilkan mencapai titik jenuh. Ada empat langkah yang dilakukan dalam analisis secara intereraktif yaitu mengumpulkan data, reduksi data, menyajikan data, dan menarik kesimpulan (verifikasi).

\section{Hasil dan Pembahasan}

Pelaksanaan Penilaian Pembelajaran Kurikulum 2013 di SD Negeri Ungaran dan SD Negeri

Serayu

\section{Penilaian Sikap}

Penilaian sikap di SD NUngaran dan SD $\mathrm{N}$ Serayu sudah dilaksanakan, setiap guru memiliki cara tersendiri dalam melaksankan penilain tersebut. Dalam penilaian sikap guru lebih banyak menggunakan teknik observasi dibandingkan teknik yang lain. Observasi. Teknik pelaksanaan penilaian dengan observasi dilaksanakan dengan langkah yang berbedabeda oleh guru, dapat paparkan sebagai berikut: (1) guru menilai dan merata-ratakan semua nilai siswa pada masing-masing kelompok dalam diskusi ketika belajar; (2) dari pengamatan sikap siswa diberikan nilai yang baik untuk semua siswa, agar siswa senang; (3) melaksanaan penilaian sikap dengan observasi dengan membagi siswa ke dalam tiga klasifikasi. Klasifikasi yang tergolong memiliki sikap sangat baik, baik, dan belum baik. Kemudianmerata-ratakan pemberian nilai yang sama pada masing-masing klasifikasi siswa.

Penilaian diri dan penilaian antar-teman. Di SD N Ungaran, tiga guru yang menjadi informan.GU1 melaksanakan teknik penilaian diri dan antara teman dengan menanyakan langsung kepada siswa secara lisan, tanpa menggunakan instrument. Penilaian itu hanya pernah dilakukan satu kali dalam semester. GU2 belum melaksanakan teknik penilaian sikap dengan penilaian diri atau antara-teman, karena menganggap teknik observasi yang dilakukan guru sudah cukup mewakili penilaian diri dan antara teman dalam mengetahui sikap siswa. GU3 juga belum melaksanakan penilaian dengan teknik penilaian diri dan antar teman, karena menurutnya anak seusia SD belum mampu menilai diri atau temannya secara objektif.Di sisi lain di SD $\mathrm{N}$ Serayu pengakuantiga guru meliputi: GS1 mengganti penilaian diri dan antara teman dengan teknik observasi, karena hal itu dirasa sudah cukup mewakili. GS2 mengaku belum pernah melaksankanpenilaian diri dan antara teman. GS3 melakukan penilaian tersebut dengan memberikan pertanyaan tertulis kepada siswa tentang hobinya, makanan kesukaan, 


\section{Jurnal Prima Edukasia, 5 (1), January 2017 - 63}

Kamiludin, Maman Suryaman

teman yang disukai, dll., sehingga dari hal itu diketahui problem yang ada dalam diri siswa.

Penilaian dengan teknik jurnal. Belum dilakukan oleh tiga guru kelas empat di SD Negeri Ungaran. Alasannya ialah karena ada yang belum paham tentang penilain jurnal seperti GU2 dan GU3. Teknik penilaian dengan jurnal belum dapat dilaksanakan karena belum terbiasa, ungkapan dari GU1. Sedangkan di SD N Serayu GS1 dan GS2 belum melakukan penilaian dengan teknik jurnal karena mengakui belum memahaminya. GS3 sudah melakukannya dengan mencatat kejadian-kejadian tertentu yang terjadi pada proses pembelajaran yang berkaitan dengan aktifitas siswa.

\section{Penilaian Pengetahuan.}

Jenis penilaian pengetahuan ini meliputi tes lisan dan tulisan.Dalam proses pembelajaran, guru SD Negeri Ungaran dan SD Negeri Serayu lebih sering menggunakan tes tulisan dari pada tes lisan, dalam menilai hasil belajar siswa. Pelaksanaan penilaian pengetahuan juga lebih banyak menggunakan tes tulis dari pada tes lisan. GU1 dan GU3 melaksanakan penilaian tes tulis instrumen mengacu pada buku guru/ siswa. Di SD N Serayu, GS1 dan GS2 menggunakan tes lisan saat proses pembelajaran berlangsung untuk merefleksi atau memberikan penguatan pada siswa terkait materi yang dibahas. Artinya bahwa belum dilaksanakan dengan struktur. Sedangkan GS3 sudah dilaksanakan dengan struktur satu kali dalam 1 tema pembelajaran.

\section{Penilaian Keterampilan}

Penilaian keterampilan meliputi; praktik, proyek, dan fortofolio.Penilaian kinerja/praktik yang dilaksanakan oleh guru di SD N Ungaran maupun SD N Serayu dilakukan pada muatan pembelajaran yang sudah jelas ada unsur praktiknya dan menghasilkan karya/produk, contohnya olah raga atau praktik-praktik yang lain seperti membuat layang-layang pada muatan pembelajaran matematika, menggambar/melukis pada muatan pembelajaran seni, membuat getuk pada muatan pembelajaran IPS. Sedang dalam muatan pembelajaran bahasa Indonesia jarang sekali dilakukan, misalnya menilai keterampilan membaca, menulis, atau berbicara siswa dalam sebuah diskusi. Penilaian dalam bentuk proyek belum dilaksanakan oleh guru, karena dengan alasan keterbatasan waktu. Di sisi lain, penilaian dalam bentuk portofolio sudah dilaksaksanakan oleh semua guru terse- but. Di sisi lain, GS3 sudah melaksanakan penilaian penilaian keterampilan baik pada portofolio, proyek maupun praktik sesuai standar kurikulum 2013.

\section{Problematika Pelaksanaan Penilaian Kurikulum 2013}

Ada beberapa problem yang ditemukan dalam pelaksanaan penilaian Kurikulum 2013 yaitu waktu dalam melaksanakan penilaian, pemahaman guru, produktivitas guru, ketidakpedulian guru dan pola pikir guru.

Tabel. 1 Problematika Pelaksanaan Penilaian Pembelajaran Kurikulum 2013

\begin{tabular}{|c|c|c|}
\hline No. & Problem & Bentuk Problem \\
\hline 1. & $\begin{array}{l}\text { Waktu } \\
\text { (Time) }\end{array}$ & $\begin{array}{l}\text { - Kompleksitas administrasi } \\
\text { - Menilai sikap ketika proses } \\
\text { pembelajaran } \\
\text { - Waktu libur sekolah } \\
\text { - Pembelajan tidak bisa tuntas } \\
\text { satu hari }\end{array}$ \\
\hline 2. & $\begin{array}{l}\text { Pemahaman } \\
\text { (understanding) }\end{array}$ & $\begin{array}{l}\text { - Traning Kurikulum } \\
\text { - Perbedaan Kurikulum } 2013 \\
\text { dan KTSP }\end{array}$ \\
\hline 3. & $\begin{array}{l}\text { Produktivitas } \\
\text { (productivity) }\end{array}$ & $\begin{array}{l}\text { - Usia } \\
\text { - Tidak menguasai IT (Gaptek) } \\
\text { - Kesehatan }\end{array}$ \\
\hline 4. & $\begin{array}{l}\text { Kepedulian } \\
\text { (caring) }\end{array}$ & $\begin{array}{l}\text { - Sudah terbiasa dengan } \\
\text { kurikulum sebelumnya } \\
\text { - Karakter bersantai }\end{array}$ \\
\hline 5. & $\begin{array}{l}\text { Pola pikir } \\
\text { (mindset) }\end{array}$ & - Mindset belum berubah \\
\hline
\end{tabular}

Siasat Problematika Pelaksanaan Penilaian Pembelajaran Kurikulum 2013

Siasat yang dilakukan guru dibagi dua yakni siasat kolektif dan siasat individual.Siasat kolektif merupakan suatu strategi yang dilakukan untuk mengatasi masalah pelaksanaan penilaian atau yang berkaitan dengan impelementasi Kurikulum 2013 dengan terencana dan terprogram. Siasat individual yang dimaksud di sini ialah cara guru dalam mengatasi kesulitan yang dihadapi dalam impelementasi Kurikulum 2013 (penilaian pembelajaran). Siasat ini sifatnya lebih pada kendala-kendala yang berupa teknis yang jalan keluarnya harus ada pada waktu itu juga, sehingga guru secepatnya dapat mengambil keputusan sendiri. Siasat ini dipengaruhi oleh kreativitas seorang guru yang dapat menyusuaikan diri dengan konteks saat terjadinya persoalan. 


\section{Jurnal Prima Edukasia, 5 (1), January 2017 - 64}

Kamiludin, Maman Suryaman

Tabel. 2 Siasat Problem Pelaksanaan penilaian pembelajaran Kurikulum 2013

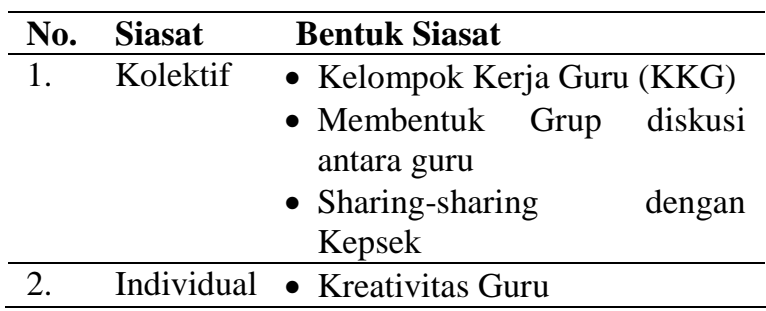

Pembahasan

Pelaksanaan Penilaian Pembelajaran

Kurikulum 2013 di SD Negeri Ungaran dan SD Negeri Serayu

Teknik pelaksanaan penilaian sikap meliputi; observasi, penilaian diri, penilaian antarteman, dan jurnal. Pada penilaian sikap dengan observasi, berbagai cara guru melaksanakan observasi tersebut, belum dapat dijamin keotentikan dari hasil penilaiannya, karena setiap siswa/individu memiliki sikap yang berbedabeda satu sama lain, sehingga tidak dapat dirata-ratakan dalam memberikan penilaian. Memang hal demikian, menjadi salah satu dari kelemahan teknik observasi pencatatan bergantung pada kejelian observer dan terkadang terjadi kekeliruan dalam pencatatannya (Kunandar, 2013, p.118).

Selanjutnya, tidak semua guru di kedua sekolah tersebut melaksanakan "penilaian diri dan antara teman". Pelaksanaanya pun terlihat belum sesuai standar (kecuali GS3), karena tidak secara struktur dan memakai instrumen. Penilaian yang baik itu ialah terencana dengan adanya instrumen (Kunandar, 2013, p.120). Begitu juga dalam penilaian dalam bentuk jurnal belum dilaksanakan oleh lima dari enam guru yang menjadi informan. Hal tersebut dipengaruhi oleh waktu yang menurut guru terbatas dalam pelaksanaanya.

Penilaian pengetahuan di kedua SD tersebut dilaksanakan lebih banyak dengan tes tulis.Memang tidak dapat dipungkiri bahwa pelaksanaan tes lisan membutuhkan estimasi waktu yang lebih lama (Kunandar, 2013, p.9), sehingga guru-guru lebih memilih tes tulis.

Penilaian keterampilan meliputi; praktik, proyek dan fortofolio.Pelaksanaan penilaian ini masih belum maksimal, karena guru belum melaksanakan semua bentuk dari penilaian keterampilan tersebut.Pada penilaian fortofolio, semua guru sudah mampu melaksanakannya. Di sisi lain, pada penilaian proyek menurut guru memerlukan waktu yang banyak, sehingga jarang dilakukan. Hal ini sejalan dengan Kunandar (2013, p.256) bahwa penilaian proyek banyak menghabiskan waktu dalam pembelajaran.Adapun penilaian dalam penilaian praktik yang dilakukan guru di SD tersebut lebih ditekankan pada kompetensi yang menghasilkan produk (membuat karya) dan olah raga.

Dalam muatan pembelajaran bahasa Indonesia khususnya jarang dilakukan, seperti penilaian keterampilan menyimak, berbicara membaca, ataupun menulis. Padahal sesungguhnya kompetensi bahasa merupakan perekat dari semua kompetensi yang lain, karena bahasa berbasis teks dan komunikatif. (Abidin, 2012, p. 167), hasil penelitian menunjukkan bahwa dalam implementasinya pada pembelajaran membaca, penilaian otetik dapat meningkatkan kemampuan membaca. Selain itu juga, dapat secara nyata mengukur kemampuan membaca siswa yang sesungguhnya serta mampu juga membentuk/membangun karakter peserta didik.

Dari 6 guru yang menjadi informan, hanya 1 guru yang melaksanakan penilaian pembelajaran susuai standar, yang hal demikian dapat dibuktikan dari hasil wawancara, dokumen, dan observasi peneliti. Ada beberapa alternatif atau suatu karakter yang dimiliki GS3 sehingga pelaksanaan kurikulum 2013 berhasil yaitu (1) kerja keras, (2) komitmen yang tinggi, (3) prinsip hidup pengabdi kepada agama, nusa dan bangsa dan (4) ketaatan beragama.

\section{Problematika Pelaksanaan Penilaian Kurikulum 2013}

Masalah waktu meliputi; (1) Pola penilaian Kurikulum 2013 yang otentik, banyak instrumen yang disiapkan.Jadi. Ada hubungan antara banyaknya instrumen penilaian (komleksitas administrasi) yang akan disiapkan guru, dengan waktu yang dibutuhkan untuk membuatnya. Sehingga, guru kurang maksimal dalam menyiap- kan instrumen.(2) Dalam pelaksanaan penilaian sikap (observasi) siswa, waktu yang bersamaan dengan proses pembelajaran menyebabkan guru belum bisa maksimal dalam pelaksanaannya.(3) Ketika libur sekolah, maka materi pada setiap pembelajaran tertentu terlewatkan. Apabila diulang akan mengganggu target yang sudah ditentukan pada tiap pembelajaran. Di sisi lain, data nilai tiap pembelajaran harus terkumpul setiap hari. Hal tersebut juga merupakan problem yang dirasakan guru dalam pelaksanaan penilaian. (4) Apabila pembelajaran tidak dapat diselesaikan satu hari, 


\section{Jurnal Prima Edukasia, 5 (1), January 2017 - 65}

Kamiludin, Maman Suryaman

maka akan berpengaruh juga pada keterbatasan guru untuk mencatat/mengahasilkan data nilai siswa setiap satu pembelajaran.Permasalahan instrumen penilaian juga dirasakan oleh guru di SD 3 Tumbuh Kota Yogyakarta yang menggunakan kurikulum nasional (Kurikulum 2013) dan International primary curriculum (IPC). Menurut (Dewi \& Mukminan, 2016, p. 20) pelaksanaan penilaian pembelajaran di SD tersebut kurang sesuai dilihat dari kesiapan instrumen dan implementasinya. Sejalan dengan itu, penelitian (Rasidi \& Setiawati, 2015, p. 166) menunjukkan bahwa ada empat faktor kesulitan guru pada penilaian pembelajaran Kurikulum 2013 yaitu: (1) pengembangan perangkat penilaian terstandar, (2) pendeskripsian hasil belajar secara kualitatif dan kuantitatif, dan (3) pemilihan instrumen penilaian sikap, pengetahuan, dan keterampilan. Sementara, Wuryadani (2009, p.4), hasil survey guru SD di KotaYogyakarta menunjukkan bahwa penentuan tolok ukur pe-nilaian berdasarkan keriteria/frekuensi penilaian afektif belum maksimal dan pembuatan format laporan tidak ada format yang baku. Sementara, Suhelayanti (2013, p.4), para guru mengakui bahwa pelaksanaan penilaian pembelajaran IPA terpadu di SD Negeri Lempuyangwangi dan SD Muhammadiyah Condongcatur memiliki keterbatasan waktu karena tahapan proses penilaian yang banyak dan tidak memiliki lab IPA untuk menunjang proses penilaian otentik.

Pemahaman guru tentang penilaian pada Kurikulum 2013 belum baik. Hal itu disebabkan beberapa hal yaitu (1) perbedaan yang cukup jauh antara model penilaian Kurikulum 2013 dengan kurikulum sebelumnya membuat guru belum terbiasa melakukan penilaian dengan pendekatan otentik (2) pelatihan Kurikulum 2013 yang diikuti belum dapat memberikan pemahaman yang memadai bagi guru (3) guru yang ikut pelatihan, tetapi hanya pada tataran UPTD menimbulkan kecemburuan sosial di antara guru yang ikut pelatihan pada tataran nasional. Dari hasil penelitian Sutrisno (2010, p.4) pada pembelajaran IPA terpadu bahwa kelemahan/tantangan pada pembelajaran IPA terpadu kurangnya peningkatan kualifikasi dan pengikutsertaan para guru dalam penataran/pelatihan dan kurangnya refrensi IPA terpadu.Hal tersebut tentunya menjadi pertimbangan kepala sekolah untuk dapat memfasilitasi guru-guru dalam menambahkan pemahaman terhadap penilaian/pembelajaran Kurikulum 2013.
Produktivitas guru menjadi salah satu problem dalam pelaksanaan penilaian pembelajaran Kurikulum 2013. Produktivitas berindikator beberapa hal: (9) faktor usia yang sudah lanjut (hampir pensiun), (2) kesehatan kurang membaik (ada guru yang memiliki penyakit akut yaitu gula darah) dan (3) masih ada guru yang gagap teknologi (Gaptek).

Kepedulian Guru. Kepedulian yang kurang dalam melaksanakan penilaian pembelajaran Kurikulum 2013 disebabkan oleh beberapa hal yaitu: tebiasa dengan kurikulum sebelumnya dan karakter bersantai.

Usaha pemerintah untuk mengubah pola pikir para guru sesungguhnya sudah dilakukan yakni dengan diadakannya pelatihan-pelatihan kurikulum. Akan tetapi, pelatihan yang dilaksanakan 2 kali atau 3 kali belumlah cukup. Hal itu mestinya dilakukan berkesinambungan, yang akhirnya dapat berhasil dalam mereformasikan mindset baru bagi guru-guru.

Berdasarkan hasil penelitian di lapangan di SD Negeri Ungaran dan SD Negeri Serayu, dalam penelitian ini menunjukkan dari enam guru yang menjadi informan setidaknya ada satu guru yang terlihat memiliki mindset sesuai harapan Kurikulum 2013, sedangkan yang lainnya masih perlu untuk terus diusahakan dengan maksimal. Pola pikir tersebut dapat dilihat dari beberapa variabel yaitu kerja keras, komitmen, prinsip hidup dan ketaatan beragama.

\section{Siasat Problematika Pelaksanaan Penilaian Pembelajaran Kurikulum 2013}

Pada bagian ini hanya memaparkan langkah-langkah guru dalam mengatasi persoalan yang dihadapi terkait pelaksanaan penilaian pembelajaran (impelementasi kurikulum). Akan tetapi, keberhasilan dari siasat yang digunakan sekolah/guru dalam mengatasi problem implementasi kurikulum tidak disinggung, karena untuk dapat mengetahui hal itu diperlukan waktu yang cukup lama. Keefektifan dari siasat guru tersebut dapat menjadi kajian selanjutnya bagi peneliti yang tertarik meneliti seputar implementasi Kurikulum 2013.

Siasat kolektif bentuknya yaitu Kelompok Kerja Guru (KKG), saling membantu/ bekerja sama antara teman sejawat (sesama guru), dan diskusi dengan kepala sekolah. Bentuk Siasat Individual (1) membuat format penilaian yang lebih sederhana (simple) menurut guru, (2) memberikan PR ketika libur sekolah agar input nilai tetap ada pada pembelajaran 


\section{Jurnal Prima Edukasia, 5 (1), January 2017 - 66}

Kamiludin, Maman Suryaman

tertentu (3) meminta bantuan kepada TU atau teman dalam penambah pemahaman IT, (4) berdiskusi dengan teman sejawat bila tidak paham tentang teknis penilaian pembelajaran, (5) kepala sekolah memotivasi guru-guru yang merupakan kiat-kiat untuk mengubah mindset.

\section{Simpulan}

Dari paparan fakta-fakta tersebut terlihat bahwa guru-guru di kedua sekolah tersebut belum melakukan penilaian pada jenis/teknik penilaian tertentu seperti penilaian dalam bentuk jurnal, penilaian diri/antara teman, penilaian praktik tidak pada semua muatan pembelajaran, dan penilaian dalam bentuk proyek masih belum dilakukan dengan maksimal. Hal itu membuktikan bahwa pelaksanaan penilaian pembelajaran yang dilakukan belum memenuhi standar kurikulum 2013. Dari 6 guru yang menjadi informan, hanya 1 guru yang melaksanakan penilaian pembelajaran susuai standar, yang hal demikian dapat dibuktikan dari hasil wawancara, dokumen, dan observasi peneliti. Adapun problematika yang dihadapi guru dalam melaksanakan penilaian pembelajaran Kurikulum 2013 meliputi waktu yang tidak cukup dalam membuat instrument penilaian yang dianggap cukup kompleks bagi guru, pemahaman guru yang masih kurang pada teknis penilaian otentik, kurangnya produktivitas guru, kurangnya kepedulian guru danmindset guru yang belum berubah. Siasat guru dalam mengatasi problematika yakni siasat kolektif dan individual.

\section{Daftar Pustaka}

Abidin, Y. (2012). Model penilaian otentik dalam pembelajaran membaca pemahaman beroreintasi pendidikan karakter. Jurnal Pendidikan Karakter, II(2), 164-178. Retrieved from http://journal.uny.ac.id/index.php/jpka/arti cle/view/1301

Ahmadi, I. K. \& Amri, S. (2014). Pengembangan \& model pembelajaran tematik integratif. Jakarta: PT. Preastasi Pustakaraya.

Depdiknas. (2006). Peraturan Kementrian Pendidikan dan Kebudayaan Nomor 66 tahun 2013, tentang Standar Penilaian Pendidikan.

Dewi, A. E. A., \& Mukminan, M. (2016). Implementasi pendekatan saintifik dalam pembelajaran IPS di middle grade SD
Tumbuh 3 Kota Yogyakarta. Jurnal Prima Edukasia, 4(1), 20-31. http://doi.org/10.21831/jpe.v4i1.7691

Haylock, D. \& Thangata, F. (2007). Key concept in teaching primary mathematics. Thousand Oaks, CA: Sage Publication.

Hosnan. (2014). Pendekatan Saintifik dan Kontekstual dalam Pembelajaran Abad 21. Bogor: Ghalia Indonesia.

Kemendikbud. (2013). Kurikulum 2013 SD.

Kemendikbud. (2013). Kurikulum 2013 SD, Panduan Teknis Penilaian Sekolah Dasar.

Kunandar. (2013). Penilaian otentik penilaian hasil belajar peserta didik berdasarkan kurikulim 2013. Jakarta: PT Rajagrafindo Persada.

Kidd, W. \& Czerniawski, G. (2010). Succesful teaching 14-19 theory practice and reflection. New Delhi, India: Sage Publication.

Majid, A. (2014). Pembelajaran tematik terpadu. Bandung: PT. Remaja Rosdakarya.

Mardapi, D. (2012). Pengukuran penilaian \& evaluasi pendidikan. Yogyakarta: Nuha Medika.

Miles, M. B., Huberman, A. M., \& Saldaña, J. (2014). Qualitative data analysis: a methods sourcebook. Los Angeles: Sage.

Nasution. (2011). Asas-asas Kurikulum. Jakarta: Bumi Aksara.

Oliva, P.F. (1992). Develoving the curriculum (thirth edition). New York, NY: Harper Collins Publisher.

Print, M. (1993). Curriculum development and design. Sydney: Allen \& Unwin.

Prastowo, A. (2014). Pengembangan bahan ajar tematik. Jakarta: Kencana.

Rasidi, M. A., \& Setiawati, F. A. (2015). Faktor-faktor kesulitan guru pada pembelajaran tematik integratif di SD Kota Mataram. Jurnal Prima Edukasia, 3(2), 155-165. http://doi.org/10.21831/jpe.v3i2.6504

Schunk, D.H. (2008). Learning theories an educational perspective. Upper Saddle River, NJ: Pearson Education.

Suhelayanti (2012). Kemampuan guru dalam mendesain dan mengimpelementasikan 
Jurnal Prima Edukasia, 5 (1), January 2017 - 67

Kamiludin, Maman Suryaman

penilaian otentik pada pembelajaran IPA Kelas IV di SD Negeri Lempuyangwangi Yogyakarta dan SD Muhammadiyah Condongcatur". Tesis magister, tidak diterbitkan. Pascasarjana Universitas Negeri Sunan Kalijaga Yogyakarta.

Sutrisno, S. (2010). Identifikasi kelemahan dan tantangan pada implementasi pembelajaran IPA terpadu di Madrasah Ibtidaiyah serta usulan solusinya. Tesis Magister, tidak diterbitkan.. Pascasarjana Universitas Negeri Yogyakarta.
Trianto. (2010). Mengembangkan model pembelajaran tematik. Jakarta: PT. Preastasi Pustaka.

Wuryadani, W. (2009) Penilaian efektif dalam pembelajaran pendidikan kewarganegaraan di sekolah dasar. Tesis magister, tidak diterbitkan. Program Pascasarjana Universitas Negeri Yogyakarta.

Yin, R.K. (2012). Studi kasus desain \& metode. Diterjemah oleh Mudzakir. M. D. Jakarta: PT RajaGrafindo Persada. 